\title{
TIPOLOGI PERUMAHAN TERENCANA BERDASARKAN KRITERIA LAYAK HUNI
}

\author{
Rizka Chairini $^{1}$, Mutiara Widyasari ${ }^{2}$, Dwira Nirfalini Aulia ${ }^{3}$ \\ ${ }^{1,2}$ Departemen Arsitektur Fakultas Teknik Universitas Sumatera Utara \\ Jl. Perpustakaan St. J07 Building, Medan, 20155, Indonesia \\ *Email: ${ }^{1}$ rizkachairini@gmail.com, ${ }^{2}$ mumutwidyasari@yahoo.com
}

\begin{abstract}
ABSTRAK
Perumahan terencana memiliki keterkaitan dengan tipologi. Dalam sebuah kawasan perumahan, tipologi akan mengarah pada upaya mengelompokan atau mengkelaskan suatu bangunan berdasarkan fungsi. Dan pengaruh pola jalan (paths), pola jalur pejalan kaki (pedestrian), pola parkir (parking), hingga pola ruang privat dan ruang publik (private space and public space). Penelitian ini bertujuan untuk mengetahui pengaruh tipologi pada perumahan layak huni, mengungkapkan aktivitas dan interaksi sesama warga serta adanya keterkaitan dengan perilaku warga perumahannya. Metode yang digunakan dalam penelitian ini berupa metode deskriptif kualitatif. Pengumpulan data dilakukan dengan cara observasi langsung, wawancara dan pembagian kuesioner dengan menggunakan tema eksplorasi. Teknik analisis data dilakukan secara deskriptif, dimana peneliti menyajikan data dengan tabel, grafik, diagram serta presentase. Proses analisa data dilakukan dengan pengumpulan data secara bersamaan. Hasil penelitian menunjukan bahwa terdapat tiga pola perumahan terencana yang terdapat di Kota Medan, yaitu pola grid-kluster, kluster dan juga grid. Dalam suatu kawasan perumahan terjadi pengelompokan bangunan berdasarkan fungsi. Area komersil terletak di dekat akses masuk menuju kawasan perumahan. Selain itu, dalam satu blok kawasan rumah terdapat tiga hingga empat tipe rumah. Pola perumahan juga dapat berpengaruh pada perilaku serta aktivitas dan interaksi warganya. Adanya ruang publik serta ruang terbuka memungkinkan terjadinya interaksi antar warganya maupun masyarakat dari luar perumahan.
\end{abstract}

Kata Kunci: Tipologi, Perumahan Terencana, Perumahan Layak Huni.

\section{PENDAHULUAN}

Dalam sebuah perumahan komersil, tipologi sangat mempengaruhi pola perumahan (pattern in housing). Secara umum tipologi berasal dari bahasa Yunani yaitu 'tipos' dan 'logos'. Tipos secara luas menunjukan variasi dari ide-ide yang sama seperti sebuah tipe, model, matrik, impressi, cetakan maupun relief. Sedangkan logos yang berarti ilmu pengetahuan. Menurut Sulistijowati (1991:12) dalam Suharjanto (2013) mengatakan bahwa tipologi mengarah pada upaya untuk mengkelaskan, mengelompokkan atau mengklasifikasikan berdasarkan aspek atau kaidah tertentu, seperti fungsi, geometrik dan juga langgam. Sejalan dengan itu, selain mempengaruhi pola bangunan di perumahan itu sendiri, tipologi akan berpengaruh pada pola perumahannya. Seperti pola jalan, pola jalur pejalan kaki, pola parkir bahkan pola ruang terbuka hijau, ruang umum dan juga pola ruang privat (Friedman, 2013).
Seperti pola perumahan yang akan berpengaruh pada perilaku penghuninya terhadap lingkungan sekitarnya. Hal ini dikatakan oleh Donota Mantey (2015) bahwa pola perumahan yang baik akan berpengaruh pada perilaku penghuninya, seperti adanya ikatan yang kuat antara warga yang satu dengan warga yang lainnya, terciptanya suatu lingkaran pertemanan, terjalinnya kerja sama (gotong royong) yang kuat pada suatu wilayah, juga adanya ruang publik yang memungkinkan warganya bertegur sapa dan melakukan aktivitas diluar rumah.

\section{METODE}

Metode penelitian yang dipakai menggunakan metode deskriptif kualitatif. Metode deskriptif kualitatif ialah metode yang dalam pelaksanaannya menggunakan data yang telah diteliti terlebih dahulu dan hasil pengamatan objek oleh peneliti. Dengan 
menggunakan tema eksplorasi dimana peneliti mengkaji lebih dalam tentang suatu kajian hingga didapatkan sebuah hasil dan kesimpulan.

\section{Metode Pengumpulan Data}

Penelitian deskriptif ini bertujuan untuk mendapatkan pengaruh tipologi pada perumahan terencana yang layak huni lewat hasil dari pengumpulan data berupa survey lapangan (observasi), pembagian kuesioner, juga pengumpulan studi pustaka sebagai landasan teori.

Alasan pemilihan ketiga perumahan tersebut ialah:

1. Usia perumahan yang sudah mencapai lebih dari 20 tahun.

2. Lokasi perumahan yang strategis (berada di tengah Kota Medan)

3. Perumahan memiliki fasilitas yang memadai guna dijadikan spot keramaian.

\section{Metode Analisis Data}

Analisis data dilakukan secara kualitatif yang berarti terdapat tapel pengamatan serta gambar pendukung lainnya. Menurut Sulistijowati (1991:12) dalam Suharjanto (2013) mengatakan bahwa tipologi mengarah pada upaya untuk mengkelaskan, mengelompokkan atau mengklasifikasikan berdasarkan aspek atau kaidah tertentu, seperti fungsi, geometrik dan juga langgam. Sehingga dari tulisan ini, batasan pengamatan dilihat dari segi fisik.

Hasil pengumpulan data-data tersebut kemudian dianalisa dan dikelompokan menjadi:

1. Tipologi berdasarkan fungsi (meliputi penggunaan ruang, struktural, simbolis dan sebagainya)

2. Tipologi berdasarkan geometrik (meliputi bentuk, prinsip, tatanan dan sebagainya)

3. Tipologi berdasarkan langgam (meliputi periode, lokasi atau geografi, politik atau kekuasaan, etnik dan budaya)

\section{ANALISIS DAN INTERPRETASI}

\section{Tipologi berdasarkan fungsi}

Menurut Sastrawan (2006), bahwa kawasan perumahan terencana biasanya sudah melakukan penataan dan penggunaan lahan sudah terbagi dengan jelas. Baik itu pembagian fungsi maupun pembagian sektor. a. Perumahan Cemara Asri

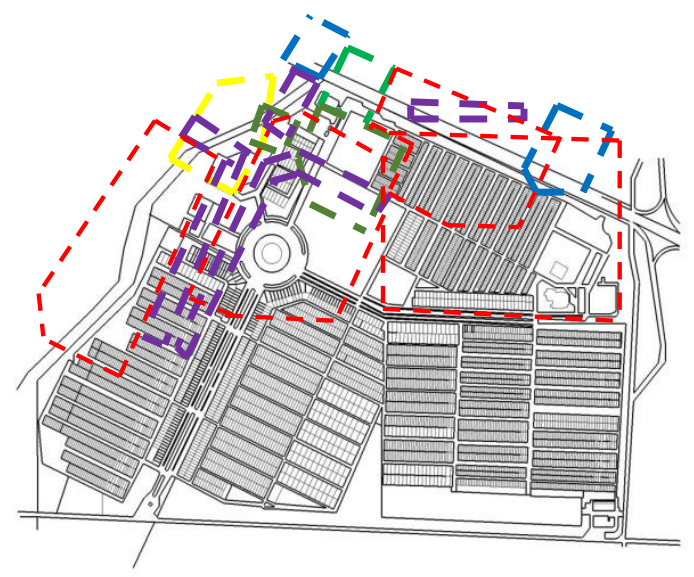

Gambar 1. Masterplan Cemara Asri

Keterangan:

- - Perumahan

- Ruko

- Clubhouse

- Fasilitas Ibadah

- - Fasilitas Pendidikan

- Fasilitas Rekreasi

b. Perumahan Citra Wisata

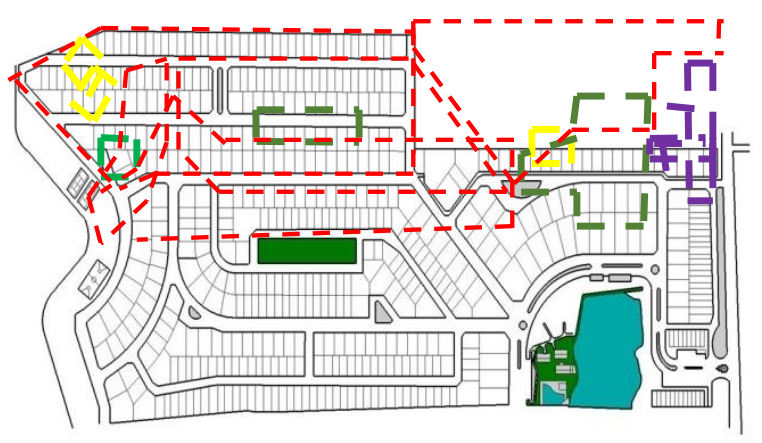

Gambar 2. Masterplan Citra Wisata

Keterangan:

$$
\begin{aligned}
& \text { - } \text { - Perumahan } \\
& - \text { - Clubhouse } \\
& - \text { - Fasilitas Ibadah } \\
& - \text { - Fasilitas Rekreasi } \\
& - \text { - Ruko }
\end{aligned}
$$


c. Perumahan Tasbi 1

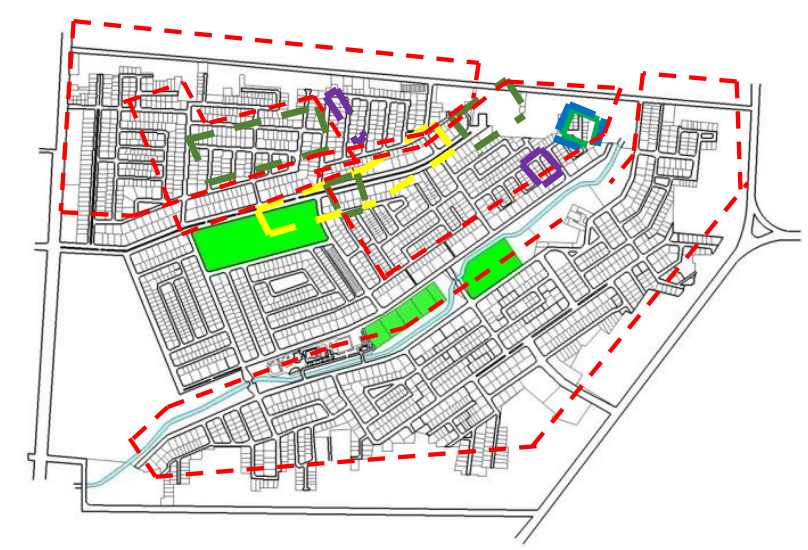

Gambar 3. Masterplan Tasbi 1

Keterangan:

- Perumahan

- Clubhouse

- Fasilitas Ibadah

- Fasilitas Pendidikan

- Easilitas Rekreasi

- Ruko

Dari gambar peta mengenai tipologi berdasarkan fungsi diatas, diperoleh data seperti Tabel 1.

Tabel 1. Analisa Sarana dan Prasarana

\begin{tabular}{|c|c|c|c|}
\hline & Komp. Cemara Asri & Komp. Citra Wisata & Komp. Tasbi 1 \\
\hline Berda-sarkan Fungsi & Perumahan dan Ruko & Perumahan- Ruko & Perumahan- Ruko \\
\hline Club-house & $\begin{array}{l}\text {-Kolam Renang } \\
\text {-Lap. Tembak } \\
\text {-Lap. Bulu Tangkis } \\
\text {-Lap. Basket }\end{array}$ & $\begin{array}{l}\text { Kolam Renang } \\
\text {-Lap. Basket } \\
\text {-Lap. Tenis }\end{array}$ & $\begin{array}{l}\text { Kolam Renang } \\
\text {-Lap. Futsal } \\
\text {-Lap. Tenis } \\
\text {-Lap. Golf } \\
\text {-Lap. Bola }\end{array}$ \\
\hline Rumah Ibadah & $\begin{array}{l}\text {-Vihara Kwan Im } \\
\text {-Mesjid Al-Musannif }\end{array}$ & Mesjid Amaliyah & Mesjid Al-Musabbihin \\
\hline Pendidikan & $\begin{array}{l}\text { Sekolah Meitreyawira } \\
\text { Chandra Kusuma School }\end{array}$ & --- & Sekolah Al-Musabbihin \\
\hline Rekreasi (RTH) & $\begin{array}{l}\text {-Bundaran Boulevard } \\
\text {-Taman Burung }\end{array}$ & $\begin{array}{l}\text {-Danau serta taman di } \\
\text { sekitaran danau } \\
\text {-RTH }\end{array}$ & RTH \\
\hline
\end{tabular}

Berdasarkan ketiga perumahan yang diamati, dapat disimpulkan bahwa fungsi dan fasilitas yang berada di ketiga perumahan merupakan faktor penting dalam menarik pengunjung dari luar rumah untuk datang ke ketiga perumahan tersebut, walaupun di beberapa tempat akan dikenakan biaya masuk. Hal inilah yang menyebabkan beberapa spot menjadi ramai pada akhir pekan dan beberapa waktu tertentu (hari libur).

1. Tipologi Berdasarkan Geometrik

Hubungan di dalam lingkungan fisik membentuk spasial (ruang), yang merupakan bagian paling mendasar dimana manusia akan saling dihubungkan di dalam ruang dan oleh ruang. Lingkungan permukiman yang merupakan bagian dari lingkungan kota mempunyal pola - pola perkembangan yang spesifik (K. Setyohadi, Bambang (2007)).

Menurut Spiro Kostof (1991) dalam K. Setyohadi Bambang (2007), dimana kota dari suatu lingkungan perrnukiman yang organik, terbentuk secara spontan, tidak terencana, pola tidak teratur (irregular) atau non geometrik. Dalam penelitian ini, terdapat tiga jenis pola perumahan yaitu 
pola perumahan grid, kluster dan juga gridkluster.

2. Perumahan Cemara Asri
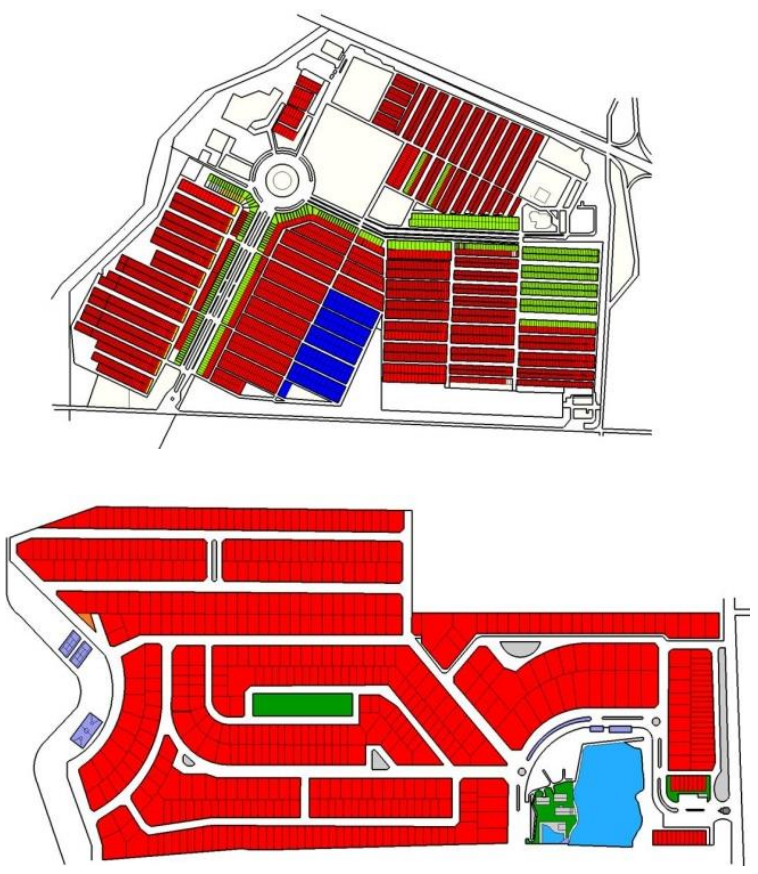

Gambar 5. Pola Perumahan Kluster

3. Perumahan Tasbi 1

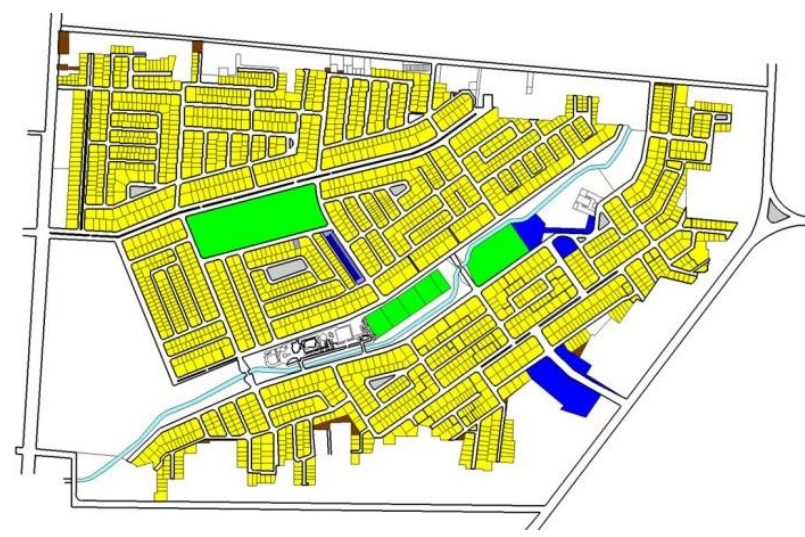

Gambar 6. Pola Perumahan Grid-Kluster

Dari gambar peta mengenai tipologi berdasarkan geometrik diatas, diperoleh data seperti Tabel 2.
Tabel 2. Analisa Tipologi Perumahan

\begin{tabular}{|c|c|c|c|}
\hline & $\begin{array}{c}\text { Komp. } \\
\text { Cemara } \\
\text { Asri }\end{array}$ & $\begin{array}{c}\text { Komp. } \\
\text { Citra } \\
\text { Wisata }\end{array}$ & $\begin{array}{l}\text { Komp. } \\
\text { Tasbi } 1\end{array}$ \\
\hline $\begin{array}{l}\text { Pola } \\
\text { Perumahan }\end{array}$ & Grid & Kluster & $\begin{array}{l}\text { Grid - } \\
\text { Kluster }\end{array}$ \\
\hline Area & -Area & -Area & -Setia \\
\hline Komer-sil & Foodcourt & Foodcourt & $\begin{array}{l}\text { Budi } \\
\text { Square } \\
\text {-Super } \\
\text { Swalayan } \\
\text {-Area } \\
\text { Foodcourt }\end{array}$ \\
\hline
\end{tabular}

Bedasarkan data dari Tabel 2 dapat disimpulkan bahwa ketiga perumahan memiliki tiga pola perumahan yang berbeda satu sama lain. Di antaranya pola perumahan grid, kluster dan juga grid-kluster. Selain itu, dua perumahan yaitu Perumahan Cemara Asri dan Perumahan Taman Setia Budi Indah memiliki area komersil yang berada di dekat pintu masuk utama perumahan dan berada di tengah kawasan perumahan. Sedangkan untuk Perumahan Citra Wisata, area komersil berada di dekat pintu masuk perumahan. Di ketiga perumahan, area komersil terdiri atas foodcourt. Namun pada perumahan Tasbi 1, terdapat swalayan dan juga square. Area square tersebut tak hanya café (yang menjual makanan) saja, melainkan berbagai toko juga terdapat di square tersebut. Seperti adanya barbershop, toko roti, minimarket hingga pet shop. Selain square dengan berbagai jenis toko, terdapat juga swalayan besar yang berada di tengah kawasan Perumahan Tasbi 1.

\section{Tipologi Berdasarkan Langgam}

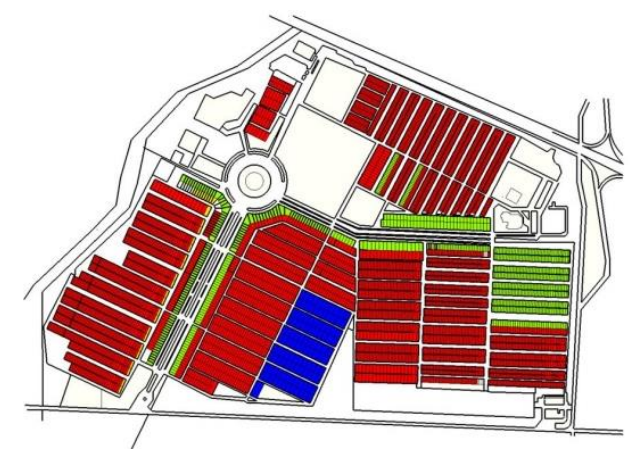

Lokasi Perumahan Cemara Asri: Jalan Cemara Boulevard, Medan Estate, Deli Serdang, Sumatera Utara 


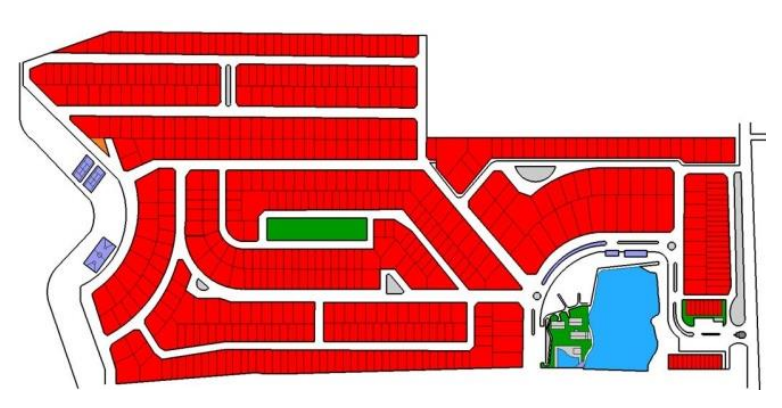

Lokasi Perumahan Citra Wisata: Jalan KaryaWisata, Medan Johor, Kota Medan, Sumatera Utara

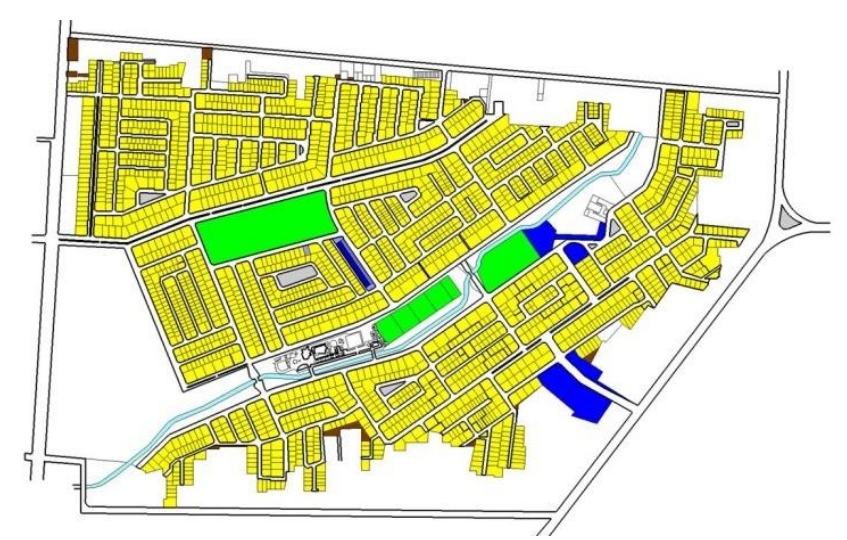

Lokasi Perumahan Taman Setia Budi Indah

1 : Jalan Setia Budi, Medan Selayang, Kota Medan, Sumatera Utara

Dari gambar peta mengenai tipologi berdasarkan langgam diatas, diperoleh data seperti Tabel 3.

Tabel 3. Analisa Pencapaian

\begin{tabular}{llll}
\hline & \multicolumn{1}{c}{ Komp. Cemara Asri } & \multicolumn{1}{c}{ Komp. Citra Wisata } & \multicolumn{1}{c}{ Komp. Tasbi 1 } \\
\hline Lokasi & Jalan Cemara Boulevard, & Jalan Karya Wisata, & Jalan Setia Budi, Medan \\
& Medan Estate & Medan Johor & Selayang \\
Jumlah Entrance & Memiliki 3 entrance & Memiliki 1 entrance & Memiliki 4 entrance \\
Akses Utama & Jalan Cemara Boulevard & Jalan Karya Wisata & Jalan Setia Budi \\
Akses Pendukung & -Jalan H. Anif & ---- & -Jalan Ring Road (Lintas \\
& -Jalan Boulevard Raya & & Sumatera) \\
& & & -Jalan Perjuangan \\
& & & -Jalan Pasar 1 \\
\hline
\end{tabular}

Dari tabel diatas, disimpulkan bahwa ketiga perumahan memiiki lokasi yang berada di tengah kota. Dengan kelebihan ini, maka ketiga perumahan dapat dengan mudah di akses dengan berbagai moda kendaraan yang ada di Kota Medan. Lokasi Perumahan Cemara Asri berada di Jalan Cemara Boulevard dan memiliki 3 entrance utama. Perumahan Citra Wisata berada di Jalan Setia Budi dan memiliki 4 entrance utama. Sedangkan Perumahan Tasbi 1 berada di Jalan Karya Wisata dan hanya memiliki 1 entrance utama saja. Untuk Perumahan Cemara Asri dan Perumahan Tasbi 1 dapat di akses dari berbagai jalan di Kota Medan (karena memiliki lebih dari satu entrance), sedangkan Perumahan Citra Wisata hanya dapat diakses melalui jalan Karya Wisata dikarenakan hanya memiliki satu entrance saja.

\section{KESIMPULAN}

Dari ketiga perumahan yang diteliti, ditemukan bahwa tipologi mempengaruhi pola rumah terencana. Seperti berdasarkan fungsi, geometrik dan juga langgam (lokasi) perumahan itu sendiri. Berdasarkan hasil pengamatan, setiap perumahan terencana memiliki beberapa kawasan yang difungsikan sebagai perumahan (rumah masyarakat), ruko, clubhouse (ruang olahraga), tempat ibadah, sekolah, dan juga area rekreasi/ruang terbuka hijau. Dari fungsi inilah, masyarakat dari luar perumahan datang untuk dapat menikmati fasilitas tersebut walaupum terdapat biaya untuk masuknya.

Selain itu, tipologi pada perumahan terencana juga didasarkan pada geometrik. Seperti Perumahan Cemara Asri memiliki pola perumahan kluster, Perumahan Citra Wisata memiliki pola perumahan grid, dan Perumahan Tasbi 1 memiliki pola perumahan grid-kluster. Di dua perumahan (Cemara Asri dan Tasbi 1) area komersil terdapat di dekat akses masuk perumahan dan juga berada di tengah kawasan perumahan. Sedangkan Citra Wisata hanya memiliki area komersil di dekat akses masuk perumahan saja.

Lokasi perumahan yang strategis banyak peminatnya. Walaupun berada ditengah kota, namun ketiga perumahan memiliki suasana yang 
tenang dan juga aman. Selain itu, adanya alternatif jalan menuju kawasan menjadi nilai tambahan bagi penghuni perumahan dikarenakan apabila satu akses masuk mengalami kemacetan, maka jalan alternatif lainnya dapat membantu untuk menuju kawasan perumahan tersebut. Namun, hal ini tidak terjadi pada Perumahan Citra Wisata.

\section{Daftar Pustaka}

Friedman, Avi. (2013) Circulation and Open Space In Affordable Townhouse Communities Vol. 32 No. 2. New York.

Mantey, Dorota (2015) The Role of Public Space In Creating Place Attachment (Example of Zacisce, Warsaw Housing Estate). Miscellanea Geographica Vol. 19 No.3. Polandia: University of Warsaw.

Setyohadi K, Bambang. (2007) Tipologi Pola Spasial dan Segredasi Sosial Lingkungan Permukiman Candi Baru. Jurnal Teknik Sipil dan Perencanaan Vol. 9 No.2. Semarang: Universitas Negeri Semarang.

Siska Soesanti, dkk. (2006) Pola Penataan Zona, Massa, dan Ruang Terbuka Pada Perumahan Waterfront (Studi Kasus: Perumahan Pantai Indah Kapuk). Dimensi Teknik Arsitektur Vol. 34 No. 2. Bandung: Universitas Khatolik Parahyangan.

Suharjanto, Gatot. (2013) Keterkaitan Tipologi Dengan Fungsi dan Bentuk: Studi Kasus Bangunan Mesjid ComTech Vol.4 No. 2. Jakarta:Universitas Bina Nusantara. 